\title{
Intellectual property commercialization as a factor of sustainable development of regional agricultural enterprises
}

\author{
Elena Khomenko*, and Darya Rakhvalova \\ Novosibirsk State Technical University, Karla Marksa Str., 20, 630073 Novosibirsk, Russia
}

\begin{abstract}
The article shows the prospects and trends of the development of the agrobiotechnology industry in Russia and at the regional level (on the example of enterprises of the agricultural sector of the Novosibirsk region). The authors found that one of the factors of sustainable development of the agricultural sector and the agrobiotechnology industry at the present stage is the commercialization of intellectual property. We identified the main intellectual property objects used in the agricultural sector they are invention, utility model, industrial design, selection invention, and trademark. We determined the foundations of their legal regimes, including the definitions, features, and criteria for registration. The article revealed spheres and enterprises of the agrobiotechnology industry for further development of strategies for intellectual property commercialization.
\end{abstract}

\section{Introduction}

Population growth on the planet, changes in the operational environment of economic entities determined by the increase in the technological level of production processes and greening trends, as well as the implementation of the state food-safety policy provide the relevance of research in the field of sustainable development of agricultural sector enterprises in the Russian Federation. At the same time, agrobiotechnology is becoming an urgent global trend and a significant component of the "green economy", including such products as biological plant protection products, biofertilizers, the results of selection and genetic engineering, products of deep processing of the plant and animal origin wastes, biological feed additives, and others. At the same time, in Russia at present, agrobiotechnology has not received the development necessary to ensure the competitiveness and sustainable development of agricultural enterprises, and the products of selection and genetics are the main imported biotechnologies.

According to the analytical agency BusinesStat, in Russia, the biotechnology sector in agriculture is in second place in terms of revenue in the biotechnology market ( $15.7 \%$ or 39.8 billion rubles) after the biopharmaceutical sector. At the same time, the turnover of the biotechnology market in Russia grew by 30\% over the period 2015-2019 and reached 254 billion rubles [1]. This growth is primarily due to the stimulation of the innovative development of economic entities and the import substitution trends strengthening, including

*Corresponding author: homenko_ev@mail.ru 
the development of innovative infrastructure and public-private partnership mechanisms, the formation of innovative territorial clusters with special conditions for the business, and the implementation of measures to support innovative companies. It leads to the investment influx in the biotechnology industry.

It is expected that in the coming years, the trends in ESG-investment in the activities of companies implementing the principles of environmental friendliness, social responsibility, and increasing the level of corporate governance, will determine the investment policies of the largest banks, funds, and private investors. Thus, the Ministry of Economic Development of the Russian Federation has developed a draft order of the Government of the Russian Federation, which defines the criteria for projects of "green financing". The taxonomy proposed in the project links environmental friendliness with the use of the best available technologies and complies with the international standards Green Bond Principles and Climate Bonds Standard, which provides opportunities for Russian companies to gain foreign investment.

The agricultural sector of the Novosibirsk region includes various subjects operating in the fields of plant production and animal industry. The reporting data of the Ministry of Agriculture of the Novosibirsk Region for the last five years show a decrease in the number of enterprises and an increase in the number of private subsidiary plots, farm households, and cooperatives in the region (Table 1).

Table 1. Dynamics of the subjects of the agricultural sector of the Novosibirsk region in 2016-2020

\begin{tabular}{|c|c|c|c|c|}
\hline Year & $\begin{array}{c}\text { Number of } \\
\text { enterprises, } \\
\text { units }\end{array}$ & $\begin{array}{c}\text { Number of private } \\
\text { subsidiary plots, } \\
\text { thousands }\end{array}$ & $\begin{array}{c}\text { Number of } \\
\text { farm } \\
\text { households, } \\
\text { units }\end{array}$ & $\begin{array}{c}\text { Number of } \\
\text { cooperatives, } \\
\text { units }\end{array}$ \\
\hline 2016 & 533 & 233 & 2420 & 20 \\
\hline 2017 & 497 & 291 & 1097 & 29 \\
\hline 2018 & 451 & 389,3 & 1097 & 32 \\
\hline 2019 & 420 & 389,3 & 1097 & 30 \\
\hline 2020 & 420 & 389,3 & 2067 & 35 \\
\hline
\end{tabular}

Source: compiled by the authors based on [2].

The structure of the agricultural sector is one of the determining factors in the formation of value chains in the industry. Thus, a decrease in the number of companies causes the risks of slowing down the technological development of the industry, localizing production, turning them into a form of home (family) farming due to the limited resources and the extremely low investment attractiveness of private subsidiary plots, farms and production cooperatives.

Decree of the Government of the Russian Federation of August 27, 2017, No. 996 "On Approval of the Federal Scientific and Technical Program for the Development of Agriculture for 2017-2025" covers the objectives of creating and implementing competitive scientific-and-technological results, and provides measures of the state support for the agricultural sector at the federal and regional levels. At the same time, the data on the volume of state support for the agricultural sector in the Novosibirsk region for 2016-2021 show a decrease in such support at all levels and the absence of direct measures for the innovation stimulation (Table 2).

The increase in funding in 2020 did not prove the change in the trend developed in the previous period, since, most likely, it was due to the implementation of measures to support economic entities in the period of the COVID-19 pandemic. 
Table 2. State support for the agricultural sector of the Novosibirsk region in 2016-2020

\begin{tabular}{|c|c|c|c|}
\hline Year & $\begin{array}{c}\text { Total amount of state } \\
\text { support, billion rubles }\end{array}$ & $\begin{array}{c}\text { Support from the } \\
\text { federal budget, billion } \\
\text { rubles }\end{array}$ & $\begin{array}{c}\text { Support from the budget } \\
\text { of the Novosibirsk } \\
\text { region, billion rubles }\end{array}$ \\
\hline 2016 & 4,9 & 2,6 & 2,3 \\
\hline 2017 & 4,1 & 1,7 & 2,4 \\
\hline 2018 & 4,75 & 2,26 & 2,49 \\
\hline 2019 & 2,9 & 1,7 & 1,2 \\
\hline 2020 & 3,47 & 1,57 & 1,9 \\
\hline
\end{tabular}

Source: compiled by the authors based on [2].

Stimulating the innovative development and increasing the investment attractiveness of agricultural enterprises engaged in the development and implementation of agrobiotechnologies requires intellectual property commercialization as a tool for the legal protection of inventions and technological leadership. At the same time, the data of the Federal Service for Intellectual Property show a low level of intellectual property commercial use in the agricultural sector. So, according to data for 2021, one of the highest indicators observed in plant production and animal industry, hunting, and the relevant services, where only 13 objects are used, 7 of which are computer programs [3]. To change the current situation, it is necessary to develop strategies for the commercialization of intellectual property of agricultural entities and stimulate their innovative activity.

\section{Methods of the research}

Current research in the field of intellectual property covers a wide range of topics, among which the assessment of the technical-and-economic parameters of intellectual property using the methods of patent analytics is of the greatest importance for our research. Thus, M. Grimaldi, L. Cricelli and F. Rogo proposed a technology audit methodology for the analysis of a patent portfolio. This methodology provides technology assessment in the context of a general business strategy and selects those patents that agree with it and ones that do not, which is necessary for making decisions [4]. S.Y. Kim and H.J. Lee, based on patent data and analysis of variance, found that the intensity of patenting activities and the quality of patents increase when an economic entity acquires a significant patent in the technological field [5].

Patent analytics, firstly, provides a retrospective analysis of the subject area. For example, a study by V.E. Ferrari, J.M.F. J da Silveira, M.E.S. Dal-Poz, describing the development of plant biotechnology trajectories, demonstrates in the mid-1990s the peak of interest in genetic engineering tools capable of manipulating plant DNA, and the transition in the 2000s from genetic engineering methods to high-yielding commercial plant varieties [6]. Second, patent analytics is a forecasting tool. For example, the use of plant stem cells, in particular, in order to increase the shelf life of agricultural products is the topic of highest relevance in agrobiotechnology (S. Aggarwal, A. Chandra) [7].

Previously, we made a study on the information openness of agricultural enterprises in the context of sustainable development [8] based on the morphological method. It covered 16 enterprises included in the Top-400 rating of the largest companies in Russia, including biofertilizer manufacturers. The results of the study made it possible to distinguish three groups of enterprises, while only one of them (PhosAgro PJSC) is included in the group, which is characterized by the maximum number of indicators in various areas of corporate responsibility disclosed for different stakeholders, in comparison with other companies. In addition, we established a positive relationship between the level of information disclosure and the company's position in the Top-400 rating. 
However, solving the problems of intellectual property commercialization requires expanding the system of analyzed indicators, including ones characterizing the creation and commercial use of objects. Firstly, we classified the intellectual property in the agricultural sector and the agrobiotechnology industry, since the choice of forms of legal protection is one of the key aspects of the development of a commercialization strategy.

The purpose of this study is to identify the most typical for the agricultural sector forms of the legal protection of intellectual property, as well as entities operating in the agrobiotechnology industry in the Novosibirsk region, for further development of a strategy for intellectual property commercialization.

At the first stage, using a formally legal method to assess positive law and the legal comparativistics method, we determined the key characteristics of intellectual property objects used in the agricultural sector.

At the second stage, based on the analysis of patent information and the method of expert assessments, we carried out an analysis of the enterprises in the agrobiotechnology industry of the Novosibirsk region.

\section{Results and Discussion}

The legal protection to the results of intellectual activity in the agricultural sector and the biotechnology industry is regulated by Article 1225 of the Civil Code, with the following types of intellectual property objects most common: invention, utility model, industrial design, selection invention, and trademark.

To determine the legal regime of intellectual property in the field of agrobiotechnology and further scenarios for their commercialization we defined possible classifications.

According to the legal nature, we divided intellectual property objects into the results of intellectual activity (invention, utility model, industrial design) and means of identification (trademark). Depending on the need for state registration, all considered objects refer to ones registreted. In this case, the possible legal forms of registration are, firstly, a patent (for an invention, utility model, industrial design, selection achievement), secondly, a certificate (for a trademark), and thirdly, an inventor's certificate (for a selection invention along with a patent). Means of identification differ in a specific set of functions: individualization, information, advertising, distinctive, warranty, and protective [9]. Table 3 shows the general characteristics of the considered objects.

Table 3. Characteristics of intellectual property used in the agricultural sector

\begin{tabular}{|c|c|c|c|}
\hline $\begin{array}{c}\text { Intellectual property } \\
\text { object }\end{array}$ & Protectability criteria & State registration & $\begin{array}{c}\text { Period of } \\
\text { protection, year }\end{array}$ \\
\hline $\begin{array}{c}\text { Trademark (Art. 1477 } \\
\text { of the Civil Code) }\end{array}$ & $\begin{array}{c}\text { Symbolism, feature of } \\
\text { novelty, distinctness }\end{array}$ & Yes (certificate) & $\begin{array}{c}10, \text { prolongation } \\
\text { for 10 }\end{array}$ \\
\hline $\begin{array}{c}\text { Invention } \\
\text { (Art. 1350 of the Civil } \\
\text { Code) }\end{array}$ & $\begin{array}{c}\text { Feature of novelty, } \\
\text { inventive level, industrial } \\
\text { applicability }\end{array}$ & Yes (patent) & 20 \\
\hline $\begin{array}{c}\text { Utility model (Art. 1477 } \\
\text { of the Civil Code) }\end{array}$ & $\begin{array}{c}\text { Feature of novelty, } \\
\text { industrial applicability }\end{array}$ & Yes (patent) & 20 \\
\hline $\begin{array}{c}\text { Selection invention } \\
\text { (Art. 1477 of the Civil } \\
\text { Code) }\end{array}$ & $\begin{array}{c}\text { Feature of novelty, } \\
\text { distinguishability, } \\
\text { homogeneity, stability }\end{array}$ & Yes (patent) & 30 \\
\hline $\begin{array}{c}\text { Industrial design (Art. } \\
1477 \text { of the Civil Code) }\end{array}$ & $\begin{array}{c}\text { Feature of novelty, } \\
\text { originality }\end{array}$ & Yes (patent) & $\begin{array}{c}5, \text { prolongation } \\
\text { for 10 }\end{array}$ \\
\hline
\end{tabular}

We conducted the analysis of the enterprises of the agrobiotechnology industry in the Novosibirsk region to identify the entities implementing the best practices for the 
development and commercial use of the intellectual property. We found out that by now a research cluster has formed in the region, the most significant subjects of which are the Siberian Federal Scientific Center of Agrobiotechnology of the Russian Academy of Sciences, the Institute of Cytology and Genetics of the Siberian Branch of the Russian Academy of Sciences, the State Scientific Center of Virology and Biotechnology "Vector". Innovative enterprises of the Biotechnopark and the Business Incubator of the Novosibirsk Region operate in the business sector (Table 4).

Table 4. Grouping of enterprises of the agrobiotechnology industry in the Novosibirsk region

\begin{tabular}{|l|l|c|}
\hline \multicolumn{1}{|c|}{ Sphere } & \multicolumn{1}{|c|}{ Enterprises } & $\begin{array}{c}\text { Inventions, utility } \\
\text { models, number }\end{array}$ \\
\hline \multirow{4}{*}{$\begin{array}{l}\text { Eco-fertilizers, feed additives and } \\
\text { vitamins }\end{array}$} & NPK "Argofarmika" LLC & 1 \\
\cline { 2 - 3 } & NPO "Alfa-Group" LLC & - \\
\cline { 2 - 3 } & MikraVita LLC & - \\
\cline { 2 - 3 } & Sibaf LLC & - \\
\cline { 2 - 3 } & PO "Sibbiopharm" LLC & 24 \\
\hline \multirow{3}{*}{$\begin{array}{l}\text { Biologicals, including biological } \\
\text { protection drugs }\end{array}$} & Biooil LLC & 2 \\
\cline { 2 - 3 } & Vector Virin LLC & 24 \\
\cline { 2 - 3 } & Mikopro LLC & - \\
\cline { 2 - 3 } & PO "Sibbiopharm" LLC & - \\
\hline \multirow{3}{*}{ Diagnostic test systems } & $\begin{array}{l}\text { Eurasian Center for Zoonotic } \\
\text { Infections LLC }\end{array}$ & - \\
\cline { 2 - 3 } & Sibitek LLC & 2 \\
\hline Biocompatible synthetic materials & Synthetic Biomatrix LLC & - \\
\hline
\end{tabular}

The grouping of subjects by types of activities made it possible to identify priority technologies for the region in the field of agrobiotechnology. Based on the results of patent searches for the companies we revealed a low level of patenting. Moreover, in some cases, patents are registered not for the company, but for the managers (for example, patent No. 2654282 belongs to the director of LLC Sibaf, S. S. Berezin). In addition, a number of enterprises registered trademarks (NPK Argofarmika LLC, NPO Alfa-Group LLC, etc.). Characterizing the financial and economic performance of companies, we noted that most of them are micro-enterprises with annual revenues not exceeding 5 million rubles, with the exception of a large enterprise PO Sibbiopharm LLC, which employs more than 350 people.

Since January 2021, the Siberian Biotechnological Scientific and Educational Center began functioning in the region, whose goals are coordinating the activities of scientific organizations and business structures of the Novosibirsk region involved in 46 initiated projects, and the implementation of measures to support projects through the allocation of subsidies from the regional government. One of the most ambitious projects is the construction of a plant for processing biomass (agricultural waste) into energy, energy sources, and fertilizers.

\section{Conclusions}

As a result, we identified the forms of the legal protection of the intellectual property that are most typical for the agricultural sector. At the same time, in the practice of enterprises in the agrobiotechnology industry in the Novosibirsk region, patenting of inventions is the most commonly available form, and utility models and trademarks are the less popular ones. The "Eco-fertilizers, feed additives and vitamins" and "Biopreparations, including biological protection drugs" areas show the greatest development in the region. The processing of biomass is a promising area for development and investment. A scientific cluster of agrobiotechnology has developed in the region. The business segment is dominated by small 
businesses, including innovative resident companies of Biotechnopark, whose patent portfolio suggests a weak level of the legal protection of intellectual property and its commercialization. This situation requires patent technological intelligence and analysis of production and technological chains to determine the level of maturity of technologies and products of the Novosibirsk region enterprises, and develop the strategies of commercialization.

\section{Acknowledgements}

The research was funded by RFBR and Novosibirsk region, project number 20-410-543001.

\section{References}

1. Analysis of the biotechnology market in Russia in 2015-2019, forecast for 2020-2024, https://businesstat.ru

2. Information on the results of the work of the agricultural sector of the Novosibirsk region for 2016-2020, http://mcx.nso.ru

3. Statistics on the use of the results of intellectual activity by type of economic activity, https://rospatent.gov.ru

4. M. Grimaldi, L. Cricelli, F. Rogo, Journal of Intellectual Capital, 2 (2018)

5. S. Y. Kim, World Patent Information, 59 (2019)

6. V. E. Ferrari, J. M. F. J. da Silveira, M. E. S. Dal-Poz, Economics of innovation and new technologies, 2, 111 (2021)

7. S. Aggarwal, A. Chandra, World Patent Information, 65 (2021)

8. E. V. Khomenko, Tomsk State University Journal of Economics, 48 (2019)

9. E. N. Kameneva, Economic Problems and Legal Practice, 3 (2018) 